Dhaka Univ. J. Biol. Sci. 21(2): 117-123, 20121 (July)

\title{
MOLECULAR IDENTIFICATION OF BACTERIA PRESENT IN THE SOILS OF THE MADHUPUR SAL AND THE SUNDERBAN MANGROVE FORESTS OF BANGLADESH
}

\author{
Minir Lal Saha, Mohammad Nurul Islam, Chaman Binta Aziz \\ AND MOHAMMad Zabed Hossain* \\ Department of Botany, University of Dhaka, Dhaka-1000, Bangladesh
}

Key words: DNA sequencing, Soil bacteria, Sunderban mangrove forests, Madhupur Sal forests, $16 \mathrm{~S}$ rRNA

\begin{abstract}
The present study aimed at identifying the soil bacterial communities in the Madhupur Sal and the Sunderban mangrove forests, the two important forests of Bangladesh. Soil bacteria were identified through sequencing of PCR-amplified fragments of bacterial $16 \mathrm{~S}$ rDNA. The results showed that the bacterial communities of the Madhupur Sal forest soils and that of the Sunderban mangrove forest soils differed in the morphology of the cells. Data presented here also showed that the bacterial communities of the Sunderban mangrove forest soils were more diverse than that of the Madhupur Sal forest soils as revealed by phylogenetic tree analysis of the $16 \mathrm{~S}$ rDNA sequences.
\end{abstract}

\section{Introduction}

Soil microbes play the critical role in decomposition of organic matter and releasing mineral nutrients in the terrestrial ecosystems ${ }^{(1)}$. Soil bacteria are essential components of the biotic community in natural forests and hence are driving the ecosystem functions(2). Although microbes show tremendous diversity among all lives on earth, the vast majority of soil bacteria still remain unidentified due mostly to the lack of suitable techniques over the decades ${ }^{(3)}$. Nevertheless, identification of bacteria is the fundamental for enhancing our knowledge about the various components and functions of any ecosystem. Development of molecular methods has paved the way to study soil microbes more reliably and rapidly.

Forests are recognized as sites of high biodiversity, where complex relationships between fauna, flora, and microflora are maintained due to the structural richness of the habitat $^{(4)}$. It is also reported that forests differing in vegetation composition exhibit differences in the microbial composition(5). Forests are one of the important natural resources in Bangladesh. Among the various forests in Bangladesh, the Madhupur Sal forest and the Sunderban mangrove forest together constitute the major proportion of all

*Author for correspondence: <zabed@du.ac.bd>. 
forest area in the country. They play important role in the economy of the country by providing forest products and employment as well as by maintaining ecological balance in the region. Studies have shown that these two forests are characteristically different in their vegetation composition and soil environment ${ }^{(6,7,8)}$. Although studies have focused mostly on the plant vegetation above ground, relatively less attention has been paid on the identification of the soil bacterial communities in these two forest types.

The main objective of the present study, therefore, was to identify soil bacteria of Madhupur Sal forests and the Sunderban mangrove forests of Bangladesh by using molecular techniques of PCR-based amplification of $16 \mathrm{~S}$ rDNA fragments followed by DNA sequence analysis.

\section{Materials and Methods}

The Madhupur Sal forests and the Sunderban mangrove forests of Bangladesh were selected for the collection of soils. The Madhupur Sal is a moist deciduous forest of its kind. The soil $\mathrm{pH}$ ranged from 4.73 to $5.36^{(6)}$. The annual rainfall of this forest area is about $1800 \mathrm{~mm}, 90 \%$ of which occurs in the period of May through October ${ }^{(9)}$. The temperature of the area is moderate ranging from 20.9 to $30.3^{\circ} \mathrm{C}(10)$. The Sunderban mangrove forests on the other hand is evergreen. The average soil $\mathrm{pH}$ is $8.0^{(11)}$. The climate of the area is characterized by relatively high temperature with daily minimum of $24^{\circ} \mathrm{C}$ in winter to a maximum of about $43^{\circ} \mathrm{C}$ in March exceeding $32^{\circ} \mathrm{C}$ during the monsoon and high humidity $(>80 \%)$ throughout the year ${ }^{(8)}$. There is relatively little variation in the rainfall between years with an average there are 80 rainy days $(>2.5 \mathrm{~mm}$ rainfall) in a year ${ }^{(8)}$.

Soils were collected at four different sites from each of the forests. The sites were distributed over a large area of at least $2 \mathrm{~km}$ from each other in order to having maximum large range of variation in soil physico-chemical properties and bacterial communities. Then, from each site, soils were collected at three locations that were $50 \mathrm{~m}$ away from each other.

Soils were collected at $0-10 \mathrm{~cm}$ depth, kept in a plastic bag and then brought to the laboratory for analyses. The soils were then kept in a refrigerator for bacteriological analysis. Soil sampling was done in September, 2008.

Bacteria present in the soil samples were grown in nutrient agar medium. The $\mathrm{pH}$ of the medium was adjusted prior to the addition of agar and sterilization. Serial dilution plate technique was used for the isolation of bacteria ${ }^{(12)}$. One gram sample was diluted (1 : 100) with $100 \mathrm{ml}$ distilled water in a sterile conical flask and then shaken well. This suspension was then used to prepare serial dilutions. One $\mathrm{ml}$ of this suspension was transferred to $9 \mathrm{ml}$ of sterile water for ten-fold $(1: 10)$ dilution and further diluted up to $10^{5}$ times. Plating in duplicate plates was made for each diluted sample. One $\mathrm{ml}$ of each of the diluted sample was taken in a sterilized Petri dish by using a pipette. Then molten 
agar medium was poured and mixed thoroughly by rotating the Petri dish, first in one direction and then in the opposite direction. After setting the medium, the plates were inverted and incubated at $37^{\circ} \mathrm{C}$ for $48 \mathrm{~h}$ in an incubator (Memmert $\mathrm{GmbH}+\mathrm{Co} \mathrm{Kg} 8540$ Schwabach). After $48 \mathrm{~h}$ of incubation, the plates having well discrete colonies were selected for counting. Then, a total of 8 colonies, each 4 colonies distinct in size and shape from each other, from each forest types were selected for molecular identification. Colonies were then sent to the Cell and Molecular Biology Laboratory, BMC, Uppsala University, Uppsala, Sweden for further analyses.

Prior to extraction of DNA, bacterial cells were cultured in nutrient agar medium. The cells were collected and spotted on to a thin layer of $1 \%$ agarose in $0.9 \%$ saline containing $0.5 \mathrm{~g} / \mathrm{ml}$ DAPI on a microscope slide. A Zeiss Axioplan 2 microscope with a CCD AxioCam camera (Zeiss) linked to the Axiovision 4.3 computerized image analysis system was used for all microscopy. The filter used for DAPI fluorescence was D360/40 $(360 \pm 20 \mathrm{~nm})$. The phase and fluorescence images were superimposed by using the program Axiovision 4.3. Shape and size of the cells were determined using the same program.

Bacterial cells were heat lysed in boiling water bath for 5 minutes and centrifuged for 1 minute at 13,000 rpm. The supernatant was used as a source of DNA in the PCR reaction. In this study, $16 \mathrm{~S}$ rDNA gene was amplified using primers mentioned before ${ }^{(13)}$. The PCR reaction was done with an initial denaturation at $95^{\circ} \mathrm{C}$ for $5 \mathrm{~min}$. The denaturation at $94^{\circ} \mathrm{C}$ for 1 minute, annealing at $60^{\circ} \mathrm{C}$ for 30 seconds and extension at $72^{\circ} \mathrm{C}$ for 30 seconds were followed by 30 cycles of amplification reactions. The final extension was for $72^{\circ} \mathrm{C}$ for $5 \mathrm{~min}$. When the PCR reaction was completed, the size of the DNA band was checked by agarose gel (1\% agar in $0.5 \mathrm{X}$ TBE solutions) electrophoresis.

DNA amplified by PCR was gel purified using Qiagen kit and then sent to Ruthbeg Laboratory, Uppsala University, Uppsala, Sweden for sequencing. The sequences generated by the automated sequencing of PCR amplified DNA was analyzed through BLAST (http://blast.ncbi.nlm.nih.gov/) program to find out the correct match of the bacterial isolates. The multiple alignments was used to construct a phylogenetic tree following Unweighted Pair Group Method with Arithmetic Mean (UPGMA) method taking 1000 replicates for bootstrap values in a BioEdit software.

\section{Results and Discussion}

The isolates obtained in this study show a large range of variation in their shape and size (Fig. 1, Table 1). On an average the cells of the isolates of the Madhupur Sal forest were larger than those of the Sunderban forests. Of the four isolates in Madhupur Sal forest soils, three were $2 \mu \mathrm{m}$ in size and the rest one was of $1.75 \mu \mathrm{m}$. On the other hand, in Sunderban forest soil, cells of only one isolate were of $2 \mu \mathrm{m}$ in size and the rest were 1 to $1.75 \mu \mathrm{m}$. In the Sunderban mangrove forest soils, cells of two isolates were thin rod; 
those of the rest were rod shaped one with chain form. Cells of the all four isolates of the Sunderban mangrove forest soils were different from each other in their shape.
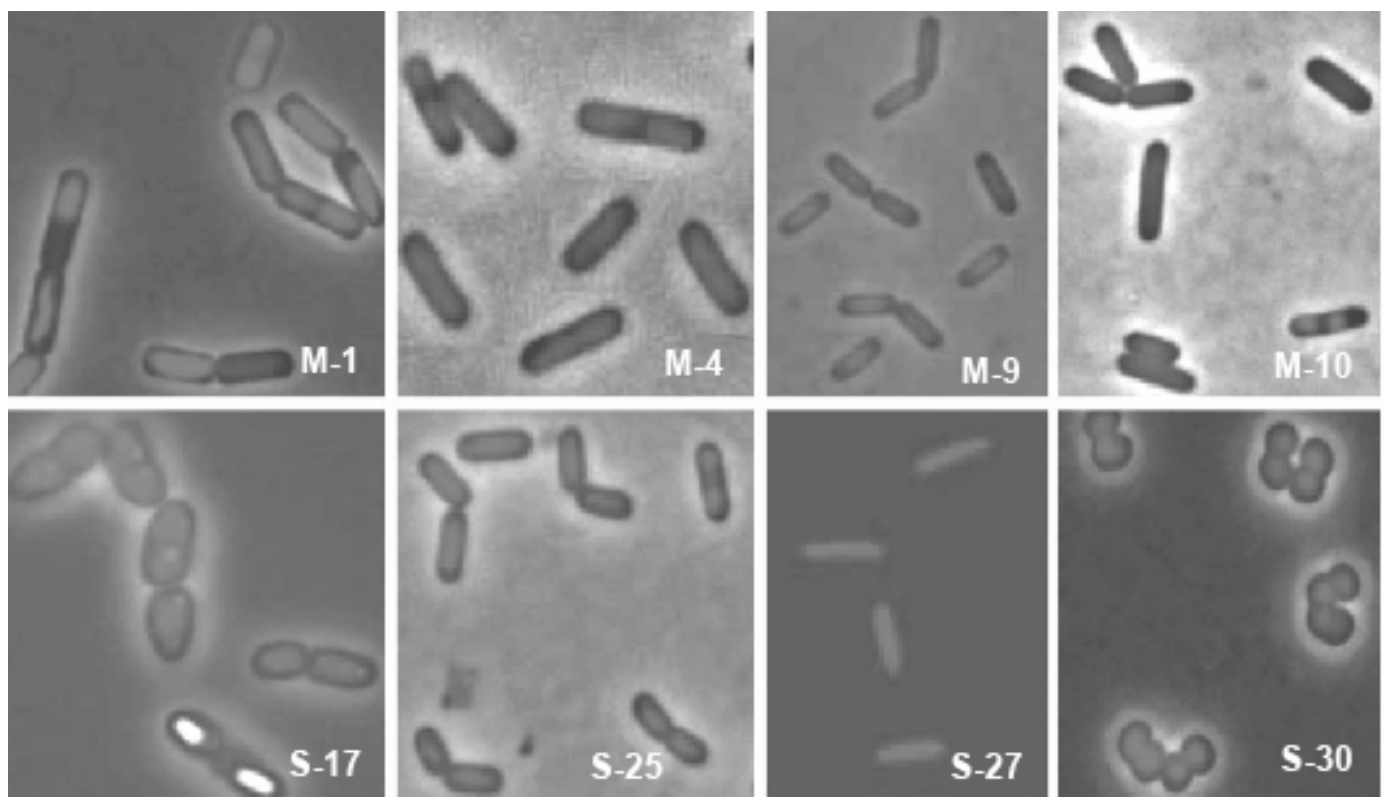

Fig. 1. Bacterial cells (1000x) isolated from the soils of Madhupur Sal forest (M-1, 4, 9 and 10) and the Sunderban mangrove forests (S-17, 25, 27 and 30).

Table 1. Morphological features of the cells of the bacterial isolate obtained from the soils of Madhupur Sal forests (M) and the Sunderban mangrove forests (S).

\begin{tabular}{llcl}
\hline \multirow{2}{*}{$\begin{array}{l}\text { Name of the } \\
\text { isolate }\end{array}$} & \multicolumn{2}{c}{ Source } & \multicolumn{2}{c}{ Morphology of the cells } \\
\cline { 3 - 4 } & & Size $(\mu \mathrm{m})$ & Shape \\
\hline M-1 & Madhupur forest soil & 2.0 & Rod, chain form \\
M-4 & Madhupur forest soil & 2.0 & Thin rod \\
M-9 & Madhupur forest soil & 1.75 & Rod \\
M-10 & Madhupur forest soil & 2.0 & Thin rod \\
S-17 & Sunderban forest soil & 2.0 & Rod \\
S-25 & Sunderban forest soil & 1.75 & thin rod \\
S-27 & Sunderban forest soil & 1.5 & Short rod \\
S-30 & Sunderban forest soil & 1.0 (diam.) & Round \\
\hline
\end{tabular}

The DNA band profile of the PCR amplification of 16S rDNA gene in the agarose gel electrophoresis is shown in Fig. 2. BLAST results of the DNA sequences of the bacteria obtained from the soils and their basic bioinformatics are shown in Table 2. Number of nucleotides obtained from the target gene ranged from 543 to 575 in the samples. The four isolates M1, M4, M9 and M10 obtained from the Madhupur forests were most 
probably of the genus Bacillus and respectively of B. cereus, B. licheniformis, B. subtilis and B. licheniformis having $100 \%$ similarity. On the other hand, the four isolates S17, S25, S27 and S30 obtained from the Sunderban forests were most probably of B. megaterium, $B$. pumilus, B. subtilis and Micrococcus luteus having 99 to 100\% similarity. The Sunderban mangrove forests seem to be more diverse having four species under two genera compared to the Madhupur Sal forests with three species under a single genus.

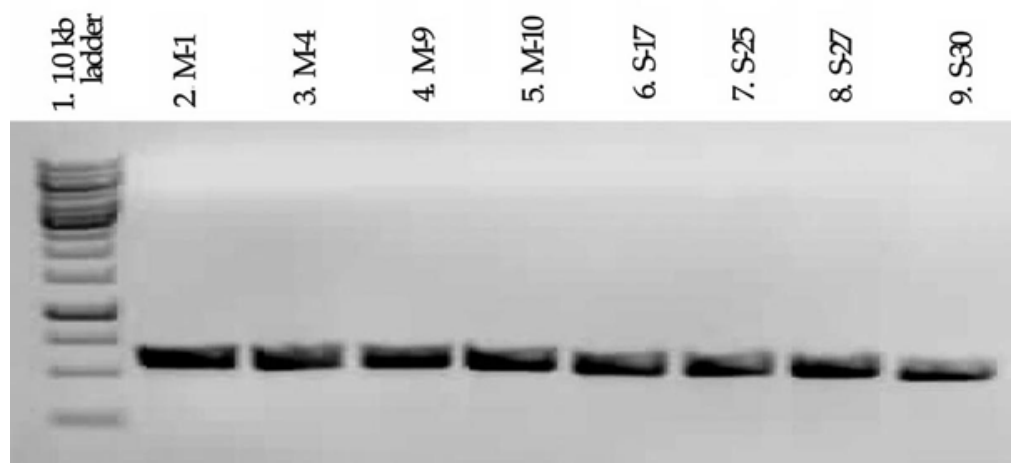

Fig. 2. DNA band profile after agarose gel electrophoresis of the PCR amplification of $16 S$ rDNA gene using universal primers where lane $1=1.0 \mathrm{~kb}$ ladder, lanes $2-5$ samples isolated from Madhupur Sal forest and Lanes 6-9 samples isolated from Sunderban mangrove forests.

Table 2. Name and basic bioinformatics of the bacteria isolated from the soils of the Madhupur Sal forest and the Sunderban mangrove forests.

\begin{tabular}{|c|c|c|c|c|c|c|c|}
\hline \multirow{2}{*}{$\begin{array}{l}\text { Name } \\
\text { of } \\
\text { isolates }\end{array}$} & \multicolumn{2}{|c|}{$\begin{array}{l}\text { Name and accession number of the bacterial } \\
\text { strain having highest similarity }\end{array}$} & \multicolumn{5}{|c|}{ Bioinformatics parameters } \\
\hline & $\begin{array}{l}\text { Accession } \\
\text { number }\end{array}$ & $\begin{array}{l}\text { Strain } \\
\text { name }\end{array}$ & Score & Bits & $\begin{array}{l}\text { Expect } \\
\text { value }\end{array}$ & $\begin{array}{l}\text { Identi- } \\
\text { ties }(\%)\end{array}$ & $\begin{array}{c}\text { Gaps } \\
(\%)\end{array}$ \\
\hline M-1 & HQ290100.1 & Bacillus cereus strain TYg2-1 & 1029 & 557 & 0.0 & 100 & 0 \\
\hline M-4 & GU434367.1 & $\begin{array}{l}\text { Bacillus licheniformis strain } \\
\text { TXc4-7 }\end{array}$ & 1033 & 559 & 0.0 & 100 & 0 \\
\hline M-9 & HQ333014.1 & Bacillus subtilis strain THt $3-1$ & 1038 & 562 & 0.0 & 100 & 0 \\
\hline M-10 & GU434367.1 & $\begin{array}{l}\text { Bacillus licheniformis strain } \\
\text { TXc4-7 }\end{array}$ & 1031 & 558 & 0.0 & 100 & 0 \\
\hline S-17 & gb|HQ333020.1 & $\begin{array}{l}\text { Bacillus megaterium strain } \\
\text { Y18-10 }\end{array}$ & 1026 & 555 & 0.0 & 99 & 0 \\
\hline S-25 & HQ268532.1 & $\begin{array}{l}\text { Bacillus pumilus strain O2A- } \\
\mathrm{X} 2\end{array}$ & 1033 & 559 & 0.0 & 100 & 0 \\
\hline S-27 & GU434366.1 & Bacillus subtilis strain TXc1-7 & 1042 & 564 & 0.0 & 99 & 0 \\
\hline S-30 & AB617561.1 & Micrococcus luteus & 987 & 534 & 0.0 & 99 & 0 \\
\hline
\end{tabular}

Phylogenetic tree constructed based on the DNA sequences of the isolates are shown in Fig. 3. The isolate S-30 of the Sunderban forests was found separated from all other clusters. Although only one isolate M1 identified as Bacillus cereus strain TYg2-1 clustered 
with S-17 identified as Bacillus megaterium strain Y18-10, all other isolates obtained from the Madhupur Sal forest clustered together. These results thus suggest that soil bacteria of the Sunderban mangrove forests were more diverse than those of the Madhupur Sal forest. Being a different genus, the isolate S-30 identified as Micrococcus luteus in the Sunderban mangrove forest soils was found reasonably separated from all other clusters.

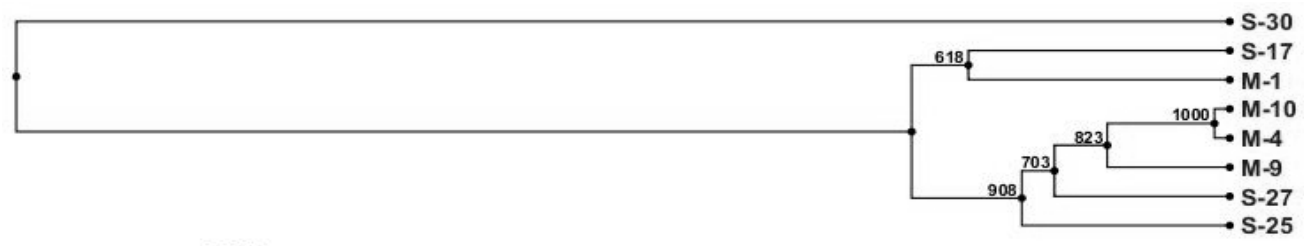

0.050

Fig. 3. UPGMA (Unweighted Pair Group Method with Arithmetic Mean) phylogenetic tree based on 16S rDNA sequences (543-575 nt). Bootstrap values for 1000 replications are indicated.

The results of the present study showed that the bacterial communities of the Madhupur Sal forest soils and that of the Sunderban mangrove forest soils differed in the morphology of the cells. Data of the present study also showed that the bacterial communities of the Sunderban mangrove forest soils were more divers than that of the Madhupur Sal forest soils. Such difference in the bacterial diversity between these two forest soils might be related with the difference in the soil environment. Tidal fluctuation and increased salinity in soil and water of the coastal habitats of the Sunderban mangrove forests has made it unique in terms of environment compared to other terrestrial forests ecosystems ${ }^{(14)}$. Further, differences in vegetation composition above ground and soil environment might also be responsible for such differences in soil bacterial communities ${ }^{(6-8)}$.

The use of molecular methods to investigate uncultivated microbes from natural environments has revolutionized our views of microbial biodiversity and ecology in recent years. Recovery and analysis of $16 \mathrm{~S}$ rDNA genes directly from environmental DNA provides a means of investigating microbial populations in any habitat, eliminating dependence on isolation of pure cultures.(4) Studies based on the extraction of total community DNA from environmental samples followed by PCR, cloning, and sequencing of $16 \mathrm{~S}$ rDNA genes have now become commonplace, often comprising one of the first steps in studying the microbiology of an environment of interest. However, the limited number of bacterial species as found in the present study was most probably related with the selection of isolates for molecular identification which was based on the morphological difference of the colonies grown in the culture medium. There is a possibility that although there were colonies similar in morphology but belonged to differed species and genus and subsequently were not selected for identification. Further, culture media might have limited the growth of many other unknown bacteria with 
different taxa. Therefore, studies based on the extraction of total community DNA from environmental samples followed by polymerase chain reaction (PCR), cloning, and sequencing of $16 \mathrm{~S}$ rDNA genes are needed to capture the whole diversity of soil bacteria in these two important forest ecosystems of Bangladesh.

\section{References}

1. Wardle DA 2002. Communities and ecosystems: Linking the aboveground and belowground components. Princeton University Press.

2. Hackl E, S Zechmeister-Boltenstern, L Bodrossy, A Sessitsch 2004. Comparison of diversities and compositions of bacterial populations inhabiting natural forest soils. Appl Environ Microbiol. 70: 5057-5065.

3. Pace NR 1997. A molecular view of microbial diversity and the biosphere. Science 276: 734-740.

4. Ahmad N, S Johri, MZ Abdin. GN Qazi. 2009. Molecular characterization of bacterial population in the forest soil of Kashmir, India. World J Microbiol Biotechnol. 25: 107-113.

5. Nusslein K and JM Tiedje 1999. Soil bacterial community shift correlated with change from forest to pasture vegetation in a tropical soil. Appl. Environ. Microb. 65: 3622-3626.

6. Hossain MZ, ML Saha, CB Aziz and S Hoque 2010. Effects of deforestation on the properties of soil of Sal forests in Bangladesh. The Dhaka Univ. J. Biol. Sci. 19: 63-72.

7. Ewel KC, RR Twilley and JE Ong 1998. Different kinds of mangrove forests provide different goods and services. Global Ecology and biogeography letters 7: 83-94.

8. Gopal B and M Chauhan 2006. Biodiversity and its conservation in the Sunderban mangrove ecosystems. Aquatic Science 68: 338-354.

9. Manalo EB 1976. Agro-climatic survey of Bangladesh. BRRI/IRRI, Los Banos, Leguna, Philippines.

10. Ghani CQ, A Alim and PR Stevens 1990. Rehabilitation and land use planning of Sal forests, parts I, II, and III. FAO/UNDP Project 85/085, Assistance to the forestry sector, Phase II, Dhaka, FAO.

11. Christensen B 1984. Ecological aspects of the Sundarbans. FAO. Rome.

12. Greenberg AE, JJ Connors, D Jekins and MAH Franson 1998. Standard methods for examination of water and wastewater. $20^{\text {th }}$ edn. APHA, Washington DC.

13. Khan MR, ML Saha, N Begum, MN Islam and S Hoque 2010. Isolataion and characterization of bacteria from rusted iron materials. Bangladesh Journal of Botany 39: 185-192.

14. Rawte T, M Padte and S Mavinkurve 2002. Incidence of marine and mangrove bacteria accumulating polyhydroxyalkanoates on the mid-west coast of India. World J. Microb. Biotechnol. 18: 655-659. 